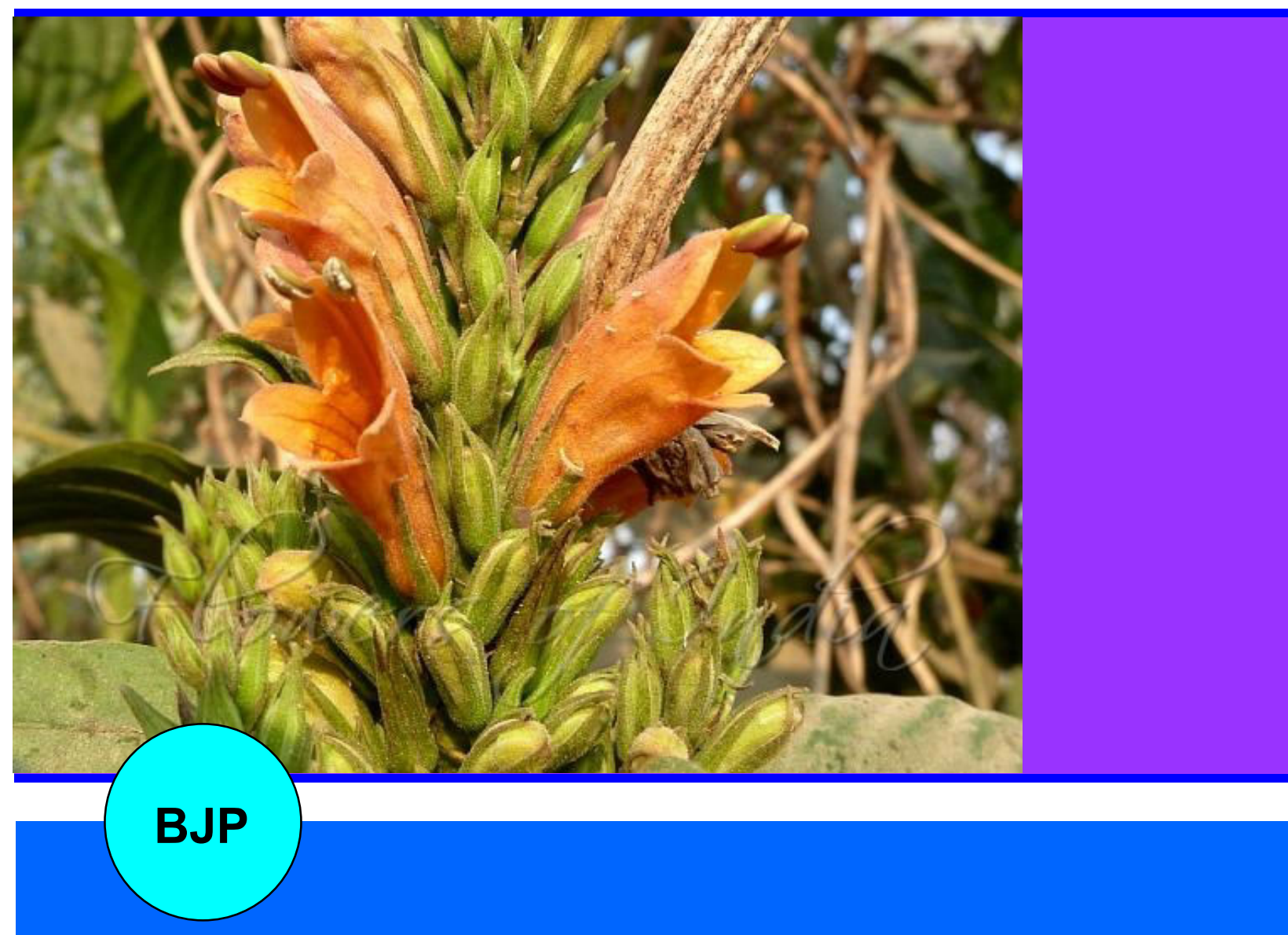

Bangladesh Journal of Pharmacology

Research Article

Study of analgesic activity of ethanol extract of Phlogacanthus thyrsiflorus on experimental animal models 


\section{Study of analgesic activity of ethanol extract of Phlogacanthus thyrsiflorus on experimental animal models}

\section{Apurba Mukherjee, Meghali Chaliha and Swarnamoni Das}

Department of Pharmacology, Assam Medical College, Dibrugarh, Assam 786 002, India.

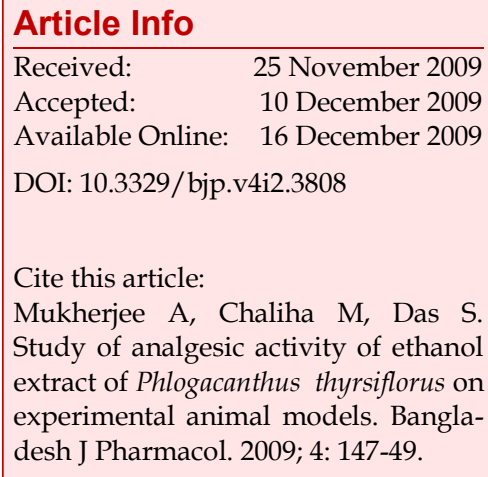

\begin{abstract}
The aim of the study was to evaluate the central and peripheral analgesic action of Phlogacanthus thyrsiflorus in experimental animal models. The extract was prepared by percolation method and acute oral toxicity testing was performed as per OECD guidelines. Analgesic activity was assessed by tail flick method (for central action) and glacial acetic acid-induced writhing test (for peripheral action). Leaves extract $(500 \mathrm{mg} / \mathrm{kg}$, p.o.) and aspirin $(100 \mathrm{mg} /$ $\mathrm{kg})$ showed significant peripheral analgesic activity $(\mathrm{p}<0.05)$. Leaves extract (500 mg/kg, p.o.) and pethidine (50 mg/kg, i.p.) also showed significant central analgesic activity $(\mathrm{p}<0.05)$. Naloxone $(1 \mathrm{mg} / \mathrm{kg}$, s.c.) was used to find the mechanism of central analgesic action. Some partial agonistic activity for the opioid receptors seems to be probable mechanism of action.
\end{abstract}

\section{Introduction}

Pain is an unpleasant sensation localized to a part of the body. It is both sensation and emotion. Pain usually occurs when peripheral nociceptors are stimulated in response to tissue injury, visceral distension, or other factors. In such situation, pain perception is a normal physiologic response mediated by healthy nervous system (Fields and Martin, 2008). Phlogacanthus thyrsiflorus is a gregarious shrub. This plant has long orange-red tubular flowers, appearing in upright spikes at the end of branches. It is an extremely popular medicinal plant. It belongs to the family Acanthaceae. It is commonly known as Rangabahaka or Teeta phool in Assamese and Lal basak in Bengali and Hindi (Patwari, 1992). It is very commonly used as a folk medicine in Assam. It is used as an anti-allergic. Curry prepared from aerial portion is given orally with rice once daily until cure (Kalita, 2008). It is also used in curing coughs and cold, chronic bronchitis, asthma and rheumatism. Different parts of the plant has been used as an anti-septic and also as a good insecticide. Fruits and leaves are taken by the Karbi tribes of Assam after burning them as a specific treatment for fever (Patwari,
1992). Flowers are antidote to pox, prevents skin diseases like sore, scabies etc. It has also been used in jaundice (Khanikar, 2005). With this variety of medicinal uses, $P$. thyrsiflorus florus seems to be a very useful medicinal plant. Though it is used in rheumatism as well, the analgesic properties of this Acanthaceae member has not been scientifically evaluated so far. Hence, the present work was undertaken to evaluate the effect of ethanol extract of leaves of $P$. thyrsiflorus on tail flick and glacial acetic acid-induced writhing models in rats and mice respectively.

\section{Materials and Methods}

Plants of $P$. thyrsiflorus were collected from the campus of Assam Medical College, Dibrugarh, Assam. The plant was authenticated by Prof. M. Islam, Department of Life Sciences, Dibrugarh University.

The leaves of the plants were air dried in shade. These were then powdered and ethanol extracts were prepared using 95\% ethanol by percolation method (Nairn, 2000) followed by evaporation in a rotator evaporator under controlled temperature and reduced pressure. A 


\begin{tabular}{|c|c|c|c|c|c|c|c|c|}
\hline \multicolumn{9}{|c|}{ Table I } \\
\hline \multicolumn{9}{|c|}{ Assessment of central analgesic action of ethanol extract of Phlogacanthus thyrsiflorus by tail flick method } \\
\hline \multirow[t]{2}{*}{ Drug } & \multirow{2}{*}{$\begin{array}{l}\text { Pre-drug reac- } \\
\text { tion time (sec) }\end{array}$} & \multicolumn{7}{|c|}{ Time (min) } \\
\hline & & 15 & 30 & 60 & 90 & 120 & 150 & 180 \\
\hline Control & $3.6 \pm 0.0$ & $3.4 \pm 0.1$ & $3.6 \pm 0.1$ & $3.7 \pm 0.1$ & $3.5 \pm 0.1$ & $3.7 \pm 0.1$ & $3.7 \pm 0.0$ & $3.8 \pm 0.4$ \\
\hline Test $(500 \mathrm{mg} / \mathrm{kg})$ & $3.6 \pm 0.1$ & $3.7 \pm 0.2$ & $4.2 \pm 0.2$ & $4.5 \pm 0.1$ & $4.6 \pm 0.2$ & $3.5 \pm 0.2$ & $3.5 \pm 0.1$ & $3.5 \pm 0.0$ \\
\hline Naloxone $(1 \mathrm{mg} / \mathrm{kg})$ & $3.6 \pm 0.0$ & $3.5 \pm 0.1$ & $3.4 \pm 0.1$ & $3.3 \pm 0.0$ & $3.0 \pm 0.1$ & $3.2 \pm 0.1$ & $3.3 \pm 0.0$ & $3.3 \pm 0.6$ \\
\hline Test + Naloxone & $3.7 \pm 0.1$ & $3.6 \pm 0.2$ & $3.7 \pm 0.2$ & $4.0 \pm 0.1$ & $3.6 \pm 0.2$ & $3.2 \pm 0.1$ & $3.1 \pm 0.1$ & $3.1 \pm 0.1$ \\
\hline Pethidine $(50 \mathrm{mg} / \mathrm{kg}$ ) & $3.7 \pm 0.1$ & $4.1 \pm 0.2$ & $5.0 \pm 0.1$ & $5.1 \pm 0.1$ & $6.9 \pm 0.1$ & $5.6 \pm 0.1$ & $4.8 \pm 0.2$ & $4.2 \pm 0.1$ \\
\hline $\mathrm{F}$ & 0.5 & 2.2 & 19.1 & 48.9 & 145.7 & 58.9 & 34.9 & 50.1 \\
\hline Df & 4,25 & 4,25 & 4,25 & 4,25 & 4,25 & 4,25 & 4,25 & 4,25 \\
\hline$p$ value & $>0.05$ & $>0.05$ & $<0.01$ & $<0.01$ & $<0.01$ & $<0.01$ & $<0.01$ & $<0.01$ \\
\hline
\end{tabular}

net weight of $35 \mathrm{~g}$ was obtained by percolating $525 \mathrm{~g}$ of dry powder of leaves.

Acute toxicity study was done as per OECD, 2006 Guidelines. (OECD, 2006 GUIDELINES).

All the animals used in the study were taken care of under ethical consideration, with approval from Institutional Ethical Committee, Assam Medical College, Dibrugarh.

One fourth of the upper bound dose of ethanol extract of $P$. thyrsiflorus from the limit test was decided to be considered for the experiments (Koneri and Balaram, 2008).

\section{Analgesia by central action}

The central analgesic activity was tested by tail flick method in Albino rats (D'Armour and Smith, 1941). Healthy rats of either sex weighing 100-200 g were divided into six groups with six animals in each group. The tail flick latencies (reaction time) of the animals were assessed by analgesiometer (Elite). Basal reaction time of radiant heat was taken by placing the tip (last 2 $\mathrm{cm}$ ) of the tail on the radiant heat source. Tail withdrawal from the heat (flicking response) was taken as the end point. A cut off period of $10 \mathrm{sec}$ was observed to prevent damage to the tail. The tail flick latencies were recorded at pre-drug, 15, 30, 60, 90, 120, 150 and $180 \mathrm{~min}$ after administration of vehicle or drugs. Ethanol extract of $P$. thyrsiflorus $(500 \mathrm{mg} / \mathrm{kg})$ was used as the test drug. Pethidine $50 \mathrm{mg} / \mathrm{kg}$, i.p. (Ghosh, 2008a) was taken as standard drug while naloxone 1 $\mathrm{mg} / \mathrm{kg}$ was used to determine mechanism of action.

\section{Analgesia by peripheral action}

The peripheral analgesic activity was tested by glacial acetic acid-induced writhing test in Albino mice (Wilkin et al., 1961). Healthy mice of either sex weighing 20$30 \mathrm{~g}$ were fasted overnight and divided into three groups with six animals in each group. An hour after administration of drugs, induction of writhing was done in mice by giving intraperitoneal injection of acetic acid at a dose of $10 \mathrm{~mL} / \mathrm{kg}$ body weight. The number of writhing responses were counted and recorded for $20 \mathrm{~min}$. Ethanol extract of $P$. thyrsiflorus $(500 \mathrm{mg} / \mathrm{kg}$ ) was used as the test drug. Aspirin was taken as standard drug at a dose of $100 \mathrm{mg} / \mathrm{kg}$ p.o. (Ghosh, 2008b).

\section{Statistical analysis}

Statistical analysis was done using one-way ANOVA followed by Dunett's test. Significance level of $<0.05$ was considered as significant (Rao, 1999).

\section{Results}

Acute oral toxicity tests found the $\mathrm{LD}_{50}$ of the leaves extract of $P$. thyrsiflorus to be $>2,000 \mathrm{mg} / \mathrm{kg}$.

The ethanol extract of $P$. thyrsiflorus and pethidine had significant central analgesic activity as compared to control $(\mathrm{p}<0.01$; Table I). Significant peripheral analgesic action was also observed with ethanolic extracts of $P$. thyrsiflorus and aspirin as compared to control ( $\mathrm{p}<0.01$; Table II).

\section{Discussion}

Our study showed that the ethanolic extract of the leaves of $P$. thyrsiflorus produced significant analgesia both centrally and peripherally. Peripherally acting analgesics act by blocking the generation of impulses at chemoreceptor site of pain, while centrally acting analgesics not only raise the threshold for pain, but also alter the physiological response to pain and suppress the patient's anxiety and apprehension (Shreedhara et al., 2009). Pretreatment with naloxone significantly decreased the reaction time producing hyperalgesia while combined treatment consisting ethanol extracts of P. thyrsiflorus (500 mg/ kg, p.o.) and naloxone $(1 \mathrm{mg} / \mathrm{kg}$, sc) produced significant decrease in tail flick latency at $60 \mathrm{~min}$ (Table I) as compared to the test drug alone. Naloxone blocks the actions of endogenous opioid 


\begin{tabular}{|c|c|c|c|}
\hline \multicolumn{4}{|c|}{ Table II } \\
\hline \multicolumn{4}{|c|}{$\begin{array}{l}\text { Assessment of peripheral analgesic action of etha- } \\
\text { nol extract of Phlogacanthus thyrsiflorus by glacial } \\
\text { acetic acid-induced writhing test in Albino mice }\end{array}$} \\
\hline Group & Drug & $\begin{array}{l}\text { Number of writhing } \\
\text { movements (mean } \pm \\
\text { SEM) } 20 \text { min }\end{array}$ & $\begin{array}{l}\% \\
\text { Protec- } \\
\text { tion }\end{array}$ \\
\hline Control & $10 \mathrm{~mL} / \mathrm{kg}$ & $69.5 \pm 1.7$ & \\
\hline Test drug & $500 \mathrm{mg} / \mathrm{kg}$ & $17.0 \pm 0.8 \mathrm{a}, \mathrm{b}$ & 75.5 \\
\hline Aspirin & $100 \mathrm{mg} / \mathrm{kg}$ & $7.0 \pm 0.4^{a}$ & 89.9 \\
\hline \multirow{3}{*}{$\begin{array}{l}\text { One-way } \\
\text { ANOVA }\end{array}$} & $\mathrm{F}$ & 943.6 & \\
\hline & $\mathrm{dF}$ & 2,15 & \\
\hline & $p$ & $<0.01$ & \\
\hline $\begin{array}{l}\mathrm{n}=6 ;{ }^{\mathrm{a}} \mathrm{p}<0 \\
\text { to standard }\end{array}$ & $\begin{array}{l}\text { when compar } \\
\text { NOVA followe }\end{array}$ & $\begin{array}{l}\text { to control; }{ }^{b} p<0.05 \text { wh } \\
\text { y Dunnet's test }\end{array}$ & ompared \\
\hline
\end{tabular}

peptides. It blocks placebo, acupuncture and stressinduced analgesia: Showing the involvement of endogenous peptides in these (Tripathi, 2008). Our study showed naloxone partially blocked the action of the test drug. This indicates the involvement of endogenous opioid peptides in the mediation of antinociceptive response of $P$. thyrsiflorus. As the analgesic action is decreased partially some other non-opioid mechanisms may also be involved.

Standard NSAIDs like aspirin offer relief from inflammatory pain by suppressing the formation of pain substances in the peripheral tissues, where prostaglandin and bradykinin were suggested to play an important role in the pain process. Prostaglandins elicit pain by direct stimulation of sensory nerve endings to other pain provoking stimuli (Kanodia and Das, 2009). Therefore, the ethanol extracts of $P$. thyrsiflorus might also suppress the formation of these substances or antagonize the action of these substances and thus exerts its peripheral analgesic activity in acetic acid induced writhing test.

Thus, the present study revealed that $P$. thyrsiflorus possesses significant central and peripheral analgesic activities.

\section{Acknowledgment}

The authors wish to thank Prof. M. Islam of Dibrugarh University for authentication of the plant.

\section{References}

D'Armour FE, Smith DL. A method for determining loss of pain sensation . J Pharmacol Exp Ther. 1941; 72: 74-79.

Fields HL, Martin JB. Pain pathophysiology and management. In: Harrison's Principles of internal medicine. Kasper DL, Braunwald E, Fauci AS, Hauser SL, Longo DL, Jameson JL (eds). 17th ed. New York, McGraw Hill, 2008, pp 81-86.

Ghosh MN. Guide to drug doses in laboratory animals. In: Fundamentals of experimental pharmacology. $4^{\text {th }}$ ed. Kolkata, India, Ghosh and others, 2008a, pp 243-56.

Ghosh MN. Toxicity studies. In: Fundamentals of experimental pharmacology. $4^{\text {th }}$ ed. Kolkata, India, Ghosh and others, 2008b, pp 176-83.

Kalita D, Bora RL. Some folk medicines from Lakhimpur district, Assam. Indian J Tradit Know. 2008; 7: 414-16.

Kanodia L, Das S. A comparative study of analgesic property of whole plant and fruit extracts of Frageria vesca in experimental animal models. Bangladesh J Pharmacol. 2009; 4: 35-38.

Khanikar G. In: Sahajlavya Bandarabar Gun. $7^{\text {th }}$ ed (Revised). Guwahati, India, Puthitirtha Prakashan, 2005, p 34.

Koneri R, Balaram R. Antidiabetic mechanisms of saponins of Momordica cymbalaria. Pharmacog Mag. 2008; 4: 197-206.

Nairn JG. Solutions, emulsions, suspensions and extracts. In: Remington: The science and practice of pharmacy. Gennaro A, Marderosian AD, Hanson GR, Medwick T, Popovich NG, Schnaare RL et al (eds). 20 th ed. Philadelphia, Lippincott Williams and Wilkins, 2000, pp 721-52.

OECD. OECD Guidelines for Testing of Chemicals [internet]. France: OECD Publishing; 2006. Section 4, Health effects: Test No. 425: Acute oral toxicity: Up and down procedure.

Patwari B. In: A glossary of medicinal plants of Assam and Meghalaya. 1 ${ }^{\text {st }}$ ed. Guwahati, India. M.N. Printers, 1992, p 98.

Rao KV. Multiple comparision test procedures. In: Biostatistics. Rao KV, Balakrishnan N (eds.). $1^{\text {st }}$ Ed. New Delhi, India, Jaypee Brothers Medical Publishers, 1999, pp 273-78.

Shreedhara CS, Vaidya VP, Vagdevi HM, Latha KP, Muralikrishna KS, Krupanidhi AM. Screening of Bauhinia purpurea Linn. for analgesics and anti-inflammatory activities. Indian J Pharmacol. 2009; 41: 75-79.

Tripathi KD. Opioid analgesics and antagonists. In: Essentials of medical pharmacology. $6^{\text {th }}$ ed. New Delhi, India, Jaypee Brothers Medical Publishers (P) Ltd, 2008, pp 453-74.

Witkin LB, Hebner CF, Gaddi F, O'Keefe E, Spilaletta P, Plummer AJ. Pharmacology of 2-amino-indane hydrochloride (SU-8629). A potent non-narcotic analgesic. J Pharmacol Exp Ther. 1961; 133: 400-08.

\section{Author Info \\ Apurba Mukherjee (Principal contact) \\ I e-mail: dr.apurba@ymail.com}

